\title{
SYSTEM DEVELOPMENT AND DATABASE SECURITY
}

\section{DONI WINATA}

165100085

Faculty of Computer, PBD 4487571-97

doniwinata@umitra.ac.id

\begin{abstract}
Basic Data (Database) Basic data (English: database) is a collection of information stored on a computer systematically so that it can be used on a computer program to obtain information from the database. Software used to manage and release queries (databases) is called a management database system (database management system, DBMS).

Computer system security in the Database is categorized in several aspects, namely:

1. Privacy / Confidentiality

2. Integration

3. Authentication

4. Availability

5. Nonrepudiation

6. Access control
\end{abstract}

Keywords: System Development and Security Database 


\section{A. INTRODUCTION}

\section{System Development and Database}

Security

Database (Database) Data base (English: database) is a collection of information stored on a computer systematically so that it can be checked using a computer program to obtain information from the database. The software used to manage and invoke queries (query) databases is called a database management system (database management system, DBMS). Database systems are studied in information science. The term "database" starts from computer science. Even though it means more and more broadly, including things outside the electronics field, this article deals with computer databases. Records similar to databases actually existed before the industrial revolution, namely in the form of ledgers, receipts and data collections related to business.

The basic concept of the database is a collection of notes, or pieces of knowledge. A database has a structured explanation of the types of facts stored in it: this explanation is called a schema. The scheme describes the object represented by a database, and the relationship between the objects. There are many ways to organize schemas, or model database structures: these are known as database models or data models. The model commonly used now is a relational model, which according to the term layman represents all information in the form of interconnected tables where each table consists of rows and columns (the actual definition uses mathematical terminology). In this model, relationships between tables are represented by using the same values between tables. Other models such as hierarchical models and network models use more explicit ways to represent relationships between tables. The term database refers to collections of interconnected data, and the software should refer to as a database management system (DBMS). If the context is clear, many administrators and programmers use the term database for both meanings. 
The data base can also be interpreted as a collection of data items that are interconnected with one another organized according to a particular scheme or structure, stored in computer hardware and with software for manipulating certain uses.

\section{Database System Development}

The development of database technology is inseparable from the development of computer technology, both in hardware (software) and software (software). The development of computer network technology and data communication is one of the contributors to the progress of the application of the database which then gave birth to a distributed database system. The impact of this development can of course be felt in our lives. Developments in the world of software also affect the development of databases, so the object-oriented database and intelligent database were born. The following table shows the development of database technology. The era of database development 1960s - File processing systems, DBMS, online information management services based on text. 1970s - Application of expert systems on a decision support system, object oriented database. 1980s - Hypertext system, which makes it possible to view databases randomly according to a key (as applied on the internet). 1990s Intelligent database system, intelligent multimedia base system.

The ultimate goal of making a Data warehouse:

$>$ Provides organizational data that is easily accessed by managers.

$>$ Data that is in datawarehouse is consistent, and is the truth.

> The data warehouse is a place where data that has been used is published.

$>$ The quality of data in Datawarehouse is reliable

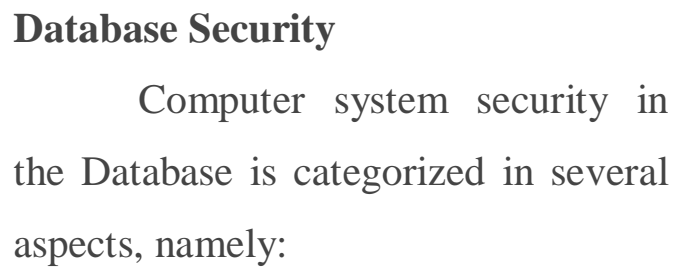
the Database is categorized in several aspects, namely: 


\section{Privacy / Confidentiality}

The main core of privacy or confidentiality aspects is an effort to safeguard information from people who are not entitled to access. Privacy is more towards data that is private in nature while confidentiality is usually associated with data given to other parties for certain purposes (for example as part of registering a service) and is only allowed for certain purposes.

\section{Integrity}

This aspect emphasizes that information must not be changed without the permission of the information owner. The existence of viruses, Trojan horses, or other users who change information without permission is an example of a problem that must be faced. An e-mail can be "intercepted" in the middle of the road, changed its contents (altered, tampered, modified), then forwarded to the destination address. In other words, the integrity of information is not maintained. The use of encryption and digital signatures, for example, can solve this problem.

\section{Authentication}

This aspect relates to the method of stating that information is truly original, people who access or provide information are truly the person in question, or the server that we are contacting is truly the original server.

4.Availability

Availability or availability aspects relate to the availability of information when needed. Information systems that are attacked or broken down can hinder or negate access to information

\section{Nonrepudiation}

It is a matter that is related to the sender, the sender cannot avoid that he sent the message / information.

\section{Access control}

User ID This aspect relates to the way access to information is managed. This is usually related to issues of authentication and privacy. Access control is often done using a combination of user ID and password or by using other mechanisms. 


\section{Aspects of computer security threats:}

1. Interruption

Is a threat to availability. Information and data contained in the computer system is damaged and deleted so that if needed, the data or information no longer exists.

\section{Inception}

Is a threat to secrecy. Information that is intercepted or unauthorized person gets access to the computer where the information is stored.

\section{Modification}

A threat to integrity, people who are not entitled to successfully intercept information traffic that is being sent and changed according to the person's wishes.

\section{Febrication}

Is a threat to integrity. People who are not entitled to successfully mimic (falsify) an existing information so that the person who receives the information thinks the information comes from the person desired by the recipient of the information.

\section{B. CONCLUSION}

Basic Data (Database) Basic data (English: database) is a collection of information stored on a computer systematically so that it can be used on a computer program to obtain information from the database. Software used to manage and release queries (databases) is called a management database system (database management system, DBMS).

The development of data-based technology can not be separated from the development of computer technology, both on hardware (hardware) and software (software). The development of computer network technology and data communication is one of the contributors to the progress of the application of data which later gave birth to a distributed database system. The impact of this development can of course be felt in our lives. Developments in the world of software also affect the development of databases, so the object-oriented database and intelligent database were born. The 
Section Class Content

following table discusses the development of data-based technology.

Computer system security in the

Database is categorized in several aspects, namely:

1. Privacy / Confidentiality

2. Integrity

3. Authentication

4. Availability

5. Nonrepudiation

6. Access con

\section{ACKNOWLEDGEMENT}

University Of Mitra Indonesia 


\section{REFERENCE(Based ISO 690 )}

A. S. Putra And O. M. Febriani, "Knowledge Management Online Application In Pdam Lampung Province," In Prosiding International Conference On Information Technology And Business (Icitb), 2018, Pp. 181-187.

[2] A. S. Putra, O. M. Febriani, And B. Bachry, "Implementasi Genetic Fuzzy System Untuk Mengidentifikasi Hasil Curian Kendaraan Bermotor Di Polda Lampung," J. Sist. Inf. Dan Manaj. Basis Data, Vol. 1, No. 1, Pp. 21-30, 2018.

[3] O. M. Febriani And A. S. Putra, "Sistem Informasi Monitoring Inventori Barang Pada Balai Riset Standardisasi Industri Bandar Lampung," J. Inform., Vol. 13, No. 1, Pp. 90-98, 2014.

[4] Putra, Arie Setya. "2018 Artikel Struktur Data, Audit Dan Jaringan Komputer." (2018).

[5] Putra, A. S. (2018, July 17). Paperplain Fundamental Create Application With Borland Delphi 7.0 University Of Mitra Indonesia. Retrieved From Osf.Io/Pbrn9.

\section{E. REFERENCE (Based APA )}

Putra, A. S., Aryanti, D. R., \& Hartati, I. (2018, November). Metode SAW (Simple Additive Weighting) sebagai Sistem Pendukung Keputusan Guru Berprestasi (Studi Kasus: SMK Global Surya). In Prosiding Seminar Nasional Darmajaya (Vol. 1, No. 1, pp. 85-97).

Sari, D. P., Febriani, O. M., \& Putra, A. S. (2018, November). Perancangan Sistem Informasi SDM Berprestasi pada SD Global Surya. In Prosiding Seminar Nasional Darmajaya (Vol. 1, No. 1, pp. 289-294).

Putra, A. S. (2018). Paperplain: Execution Fundamental Create Application With Borland Delphi 7.0 University Of Mitra Indonesia.

Putra, A. S., Sukri, H., \& Zuhri, K. Sistem Monitoring Realtime Jaringan Irigasi Desa (JIDES) Dengan Konsep Jaringan Sensor Nirkabel. IJEIS (Indonesian Journal of Electronics and Instrumentation Systems), 8(2), 221232.

Darmawan, A., Yuliawati, D., Marcella, O., \& Firmandala, R. (2016). Sistem Absensi dan Pelaporan Berbasis Fingerprint dan SMS Gateway. EXPLORE, 7(1).

Febriani, O. M., Wahyuni, T., \& Yusuf, S. (2017). DESIGN OF WEBSITE-BASED INFORMATION SYSTEM FOR EDOCUMENT ADMINISTRASI IN THE COMMUNITY SERVICE UNIT (A Case Study at Rajabasa District). INTERNATIONAL JOURNAL OF 
COMPUTERS \& TECHNOLOGY, 16(7), 7010-7020.

Febriani, O. M., \& Wahyuni, T. (2017, October). PERANCANGAN SISTEM E-DOCUMENT ADMINISTRASI LOGBOOK PENELITIAN PADA UNIT LAYANAN DI BANDAR LAMPUNG. In Prosiding Seminar Nasional Darmajaya (Vol. 1, No. 1, pp. 187-194).

Febriani, O. M., \& Permadi, A. B. (2017). Implementasi Sistem Aplikasi Data Bimbingan dan Pelanggaran Siswa pada Sekolah Menengah Atas di Lampung Tengah dengan Metode Analisis dan Desain Sistem Terdistribusi (SSAD). EXPERT, 7(1).

Febriani, O. M., \& Ambarwati, L. (2015). PERANCANGAN APLIKASI PENGOLAHAN DATA PENJUALAN UKM KELANTING KHAS TELO DESA SIDOHARJO KECAMATAN JATI AGUNG KABUPATEN LAMPUNG SELATAN. Jurnal Teknologi Informasi dan Bisnis Pengabdian Masyarakat Darmajaya, 1(1), 77-95.

Febriani, O. M. (2015). Rancang Bangun Aplikasi Ecommercemenggunakan Freewebstore pada UKM Kelanting di Desa Sidoharjo Lampung Selatan. Prosiding Sembistek 2014, 1(02), 446-458. 